\title{
Enzyme disintegration with spatial resolution reveals different distributions of sludge extracellular polymer substances
}

\author{
Fan Lü ${ }^{1}$, Jingwen Wang ${ }^{1}$, Liming Shao ${ }^{1,2,3}$ and Pinjing $\mathrm{He}^{1,2,3^{*}}$
}

\begin{abstract}
Background: To understand the intrinsic role of hydrolytic enzymes in sludge treatment, particularly their effect on the digestibility and dewaterability of sludge, activated sludge flocs were disintegrated using various techniques that included different enzymes (amylase, cellulase, proteinase, DNase, and polygalacturonase), pH adjustment, and temperature adjustment. The effectiveness of each enzyme treatment was pinpointed by quantifying the spatial distribution of each type of organic matters (protein, polysaccharide, DNA, fluorescent organics) in outer layer extracellular polymeric substances (EPS), inner layer EPS, and cells.
\end{abstract}

Results: Most hydrolytic enzymes functioned only owing to a temperature or $\mathrm{pH}$ effect. The release of organic matter from the interior fraction of EPS to the exterior fraction was prompted under high $\mathrm{pH}$ and temperature even without enzyme addition. The effectiveness of enzyme addition was only significant for cellulase and polygalacturonase treatments. Polygalacturonase unexpectedly increased the total EPS polysaccharides up to seven times, accompanied with improved dewaterability, while the amount of EPS proteins was almost unchanged. Combining chemical and morphological evidence, a new conceptual model considering the spatial distribution of polygalacturonic acid-like matter, proteins, cellulose, and other organics in EPS was proposed.

Conclusions: Polygalacturonic acid-like matter hydrolysis caused significant release of polysaccharides. Polygalacturonase released polysaccharides while keeping proteins unreleased. Temperature and pH adjustment were as effective as enzyme at sludge disintegration. Cellulose hydrolysis led to massive release of all kinds of organic matters. A new conceptual sludge structure model regarding organic components is proposed.

Keywords: Polygalacturonase, Polygalacturonic acid, Excitation and emission matrix, Environmental scanning electron microscope, Parallel factor analysis, Sludge flocs, Micro assembly

\section{Background}

The dewaterability and digestibility of waste-activated sludge is of great importance in the treatment of this material. Various organic substances that comprise sludge, especially extracellular polymeric substances (EPS), are the well-known obstacles to digestion and dewatering [1], and pretreatment is often applied to overcome these obstacles [2-4]. Among the many

\footnotetext{
*Correspondence: solidwaste@tongji.edu.cn

${ }^{3}$ Centre for the Technology Research and Training on Household Waste in Small Towns and Rural Area, Ministry of Housing and Urban-Rural Development (MOHURD) of China, Shanghai, People's Republic of China Full list of author information is available at the end of the article
}

pretreatment methods that aim at deconstructing EPS, enzymatic pretreatment stands out for economic, safety, and practical reasons. Because EPS is composed mainly of proteins and polysaccharides such as amylum and cellulose [5,6], as well as minor fractions such as DNA and humic-like substance, hydrolytic enzymes targeting such polymers are frequently used in the pretreatment of sludge or for EPS extraction, e.g., protease [7-11], $\alpha$-amylase [7, 8, 10-13], endogenous amylase [9], cellulase [8], lipase [11], pectinase [13], and DNase [13], individually, sequentially [13], or mixedly [11].

Unfortunately, there are still several unsolved problems in the current applications of enzymes for sludge 
treatment. For example, enzymatic treatments do not dramatically improve sludge digestibility. The choice of enzymes mainly has been usually limited to amylase and protease, so massive quantities of enzymes are needed to hydrolyze the proteins and polysaccharides that comprise the huge amount of EPS (200-500 mg/g volatile solids) in sludge [1]. The concomitant influences of temperature and $\mathrm{pH}$ adjustment usually have been neglected. Further, sludge treatment using only one enzyme usually yields unexpected results; to compensate for this, a complex mixture of enzymes is often used for better effect. However, the mechanism by which each enzyme in a mixture works is unknown, leaving the problem of how to decide the "recipe" of a complex enzyme mixture unsolved. Studies on hydrolyzing EPS lack specific details, such as what roles various types of organic matter have in EPS and what kind of enzyme can disintegrate EPS efficiently.

The present study was conducted to understand the intrinsic role of hydrolytic enzymes on EPS structure and consequently on the digestibility and dewaterability of sludge. Activated sludge flocs were disintegrated using different enzymes or using only $\mathrm{pH}$ adjustment or temperature adjustment. The effectiveness of each enzyme treatment on different organics was pinpointed by quantifying the spatial distribution of each type of organic matter (proteins, polysaccharides, DNA, fluorescent organics) in outer layer EPS, inner layer EPS, and cells. The application of fractionation approach was to make a better understanding on the roles of each organic matter on the flocculation of sludge aggregation by studying their distributions at different layers, which are partially important in sludge particles bridging and flocculating. In addition, principal component analysis was used to analyze the effect of different parameters on organic matters' distribution. Environmental Scanning Electron Microscopy was used to visualize the morphology of sludge after different hydrolysis treatments. Special emphasis was placed on examining an unexpected polysaccharide-releasing, protein-conserving effect of polygalacturonase treatment. As a result, a new conceptual model describing the distribution of various organic compounds in EPS was developed.

\section{Methods}

\section{Materials}

The activated sludge used in this study was collected from a municipal wastewater treatment plant located at Shanghai $\left(120^{\circ} 51^{\prime} \mathrm{E}, 30^{\circ} 40^{\prime} \mathrm{N}\right)$, treating $93 \%$ municipal wastewater and $7 \%$ industrial wastewater through anoxia-anaerobic-aerobic process. The sludge had a total solids (TS) content of $3 \% \mathrm{wt}$ and a volatile solids (VS) content of $68 \% \mathrm{dw}$. The content (dry weight basis) of polysaccharides, proteins, and DNA content was 11.7, 37 , and $3 \% \mathrm{dw}$, respectively.

Five kinds of hydrolytic enzymes were used separately to specifically target polysaccharides, proteins, or DNA. Three enzymes were used to attack different polysaccharides: $\alpha$-amylase (Sigma, Product No.: 10070-10G, about $50 \mathrm{U} / \mathrm{mg}$ derived from Bacillus subtilis, to be used at $\mathrm{pH}$ 6.9 and $25{ }^{\circ} \mathrm{C}$ ), cellulase (Sigma, Product No.: C2605$50 \mathrm{~mL}$, at least $1000 \mathrm{U} / \mathrm{g}$ derived from Aspergillus sp., to be used at $\mathrm{pH} 8.0-8.2$ and $40{ }^{\circ} \mathrm{C}$ ), and polygalacturonase (Sigma, Product No.: 17389-10G, greater than $1 \mathrm{U} / \mathrm{mg}$ derived from Aspergillus niger, to be used at $\mathrm{pH} 4.0$ and $50{ }^{\circ} \mathrm{C}$ ). Proteins were targeted using proteinase (Yinggong Trading Co. Ltd., Shanghai, China, Product No.: LG1036, at least 200 units from Bacillus licheniformis, to be used at $\mathrm{pH} 6.0-8.5$ and $\left.50-60{ }^{\circ} \mathrm{C}\right)$. Lastly, DNA was attacked using DNase (Sigma, Product No.: DN25-10MG; at least $85 \%$ protein and at least $400 \mathrm{Kunitz}$ units $/ \mathrm{mg}$ protein derived from bovine pancreas, to be used at $\mathrm{pH} 7-8$ ).

\section{Enzymatic treatment}

Experiments were conducted in a constant-temperature incubator in magnetically stirred beakers that were sealed with waxed film. The dosages of enzymes, $\mathrm{pH}$, and temperature for each treatment are listed in Table 1 . The $\mathrm{pH}$ of the raw sludge was adjusted using hydrochloric acid and sodium hydroxide solutions to the optimal value (according to the producers' suggestion and our preliminary trials) for each enzyme prior to enzyme addition.

\section{Table 1 Dosage of enzymes}

\begin{tabular}{lclll}
\hline Treatment no. & pH & Enzyme & $\begin{array}{l}\text { Enzyme } \\
\text { dosage } \\
(\mathbf{U} / \mathbf{1 0 0} \mathbf{~ m L} \\
\text { raw sludge) }\end{array}$ & $\begin{array}{l}\text { Temperature } \\
\left({ }^{\circ} \mathbf{C}\right)\end{array}$ \\
\hline C-pH4-T35 & 4.0 & Control & 0 & 35 \\
C-pH4-T55 & & & & 55 \\
C-pH7-T35 & 6.9 & Control & 0 & 35 \\
C-pH7-T55 & & & & 55 \\
C-pH8-T35 & 8.0 & Control & 0 & 35 \\
C-pH8-T55 & & & & 55 \\
Pec-pH4-T35 & 4.0 & Polygalacturo- & 420 & 35 \\
Pec-pH4-T55 & & nase & & 55 \\
Amy-pH7-T35 & 6.9 & a-Amylase & 250 & 35 \\
Amy-pH7-T55 & & & & 55 \\
Pro-pH7-T35 & 6.9 & Proteinase & 1000 & 35 \\
Pro-pH7-T55 & & & & 55 \\
Cel-pH8-T35 & 8.0 & Cellulase & 500 & 35 \\
Cel-pH8-T55 & & & & 55 \\
DNa-pH8-T35 & 8.0 & DNase & 1700 & 35 \\
DNa-pH8-T55 & & & & 55 \\
\hline
\end{tabular}


Since sludge digestion performs differently in acid, neutral, and alkaline environment, a control group of sludge samples without enzyme addition was prepared at each $\mathrm{pH}$ condition. Following $\mathrm{pH}$ adjustment and enzyme addition, the sludge samples were incubated at 35 or $55^{\circ} \mathrm{C}$. The optimal temperature for each enzyme we used is either around 35 or $55^{\circ} \mathrm{C}$. Furthermore, these are typical temperatures for mesophilic or thermophilic digestion. Control groups without enzymes were incubated under both temperatures, too. Gentle alkaline environment had been reported to promote sludge digestion but usually requiring long duration from 4 days to 20 days $[14,15]$. Since we focus on enzymatic pre-treatments in this study, samples for analysis were collected 1, 2, and $5 \mathrm{~h}$ after incubation began, so that we could detect the changes as incubation continued and made sure the enzymes were still active. Each treatment was conducted in triplicate.

\section{EPS extraction and stratification}

Based on its strength of binding to cells, EPS was extracted and stratified through centrifugation and ultrasonication into four fractions: "supernatant," "slime," "loosely bound EPS" (LB-EPS) and "tightly bound EPS" (TB-EPS). The final pellet that remained after EPS extraction was mainly composed of microbial cells and unextractable EPS. The extraction procedure suggested by $\mathrm{Yu}$ et al. [16] was followed with some modification. An additional file describes the detailed procedure (see Additional file 1).

The aqueous suspended solutions of the enzymes themselves were stratified according to the same method, and every content was determined as sludge samples. Therefore, the reported values were subtracted from the enzyme background.

\section{Determination of organic components}

The TS and VS contents of raw sludge were measured as the mass loss in samples following heating at 105 and $600{ }^{\circ} \mathrm{C}$, respectively. The polysaccharides content was measured using Anthrone colorimetry [17] on sludge samples that were mixed with $50 \mathrm{~mL} 0.5 \mathrm{M} \mathrm{H}_{2} \mathrm{SO}_{4}$ and autoclaved at $121{ }^{\circ} \mathrm{C}$ for $1 \mathrm{~h}$. Protein content was measured using the Lowry method [18] the same on sludge samples that were mixed with $50 \mathrm{~mL} 0.5 \mathrm{M} \mathrm{H}_{2} \mathrm{SO}_{4}$ and autoclaved at $121{ }^{\circ} \mathrm{C}$ for $1 \mathrm{~h}$. DNA content was measured using diphenylamine colorimetry with $1 \mathrm{~h}$ incubation at $60{ }^{\circ} \mathrm{C}$ on sludge samples that had been subjected to two cycles of bead grinding at $6300 \mathrm{rpm}$ for $2.5 \mathrm{~min}$ each.

After extraction, each EPS fraction was tested for polysaccharides, proteins, external DNA (eDNA), dissolved organic carbon (DOC), and dissolved nitrogen (DN). The determination of polysaccharides, protein, and eDNA followed the Anthrone colorimetry, Lowry method, and diphenylamine colorimetry, respectively. DOC and DN were analyzed using a Total Carbon/Total Nitrogen analyzer (TOC-V CPN, TNM-1, Shimadzu, Kyoto, Japan).

Raw sludge and pellets remaining after EPS extraction were first lyophilized and then tested for carbon, nitrogen, and hydrogen content using an element analyzer (Vario EL III, Elementar, Hanau, Germany).

\section{Fluorescent excitation-emission matrix analysis}

Three-dimensional fluorescent excitation-emission matrix (EEM) analysis was performed using a Cary Eclipse Fluorescence Spectrophotometer (VARIAN, Santa Clara, CA, USA) to obtain the relative content of fluorescent organics in each fraction. The fluorescence was collected using an excitation wavelength of 200$550 \mathrm{~nm}$ and an emission wavelength of 250-600 nm. Parallel factor analysis (PARAFAC) was applied to the EEM data to qualitatively and quantitatively analyze the main fluorescent substances. The detailed procedure for EEM and PARAFAC analyses is given by Lü et al. [19].

\section{Environmental scanning electron microscopy (ESEM)}

Environmental scanning electron microscopy (ESEM) was performed using a Quanta 250 (FEI, Hillsboro, OR, USA) to observe structural changes of biological samples due to enzyme treatment. Duplicate images of each sample were made at $500 \times, 1000 \times, 2000 \times, 5000 \times$ and $10,000 \times$ magnifications.

\section{Determination of sludge dewaterability}

The dewaterability of sludge samples was evaluated according to the TS content of cakes obtained by centrifuging sludge at $2000 \times g$ for $10 \mathrm{~min}$.

\section{Statistic analysis}

In order to distinguish the effect of control group and experiment group at the same $\mathrm{pH}$, analysis of variance (i.e., ANOVA analysis) was applied on the contents of polysaccharides, proteins, and eDNA in supernatant and TB-EPS fraction. $\mathrm{pH} 4.0$ group includes $\mathrm{pH} 4.0$ control and polygalacturonase-added group; $\mathrm{pH} 6.9$ group includes pH 6.9 control, amylase-added group, and proteinase-added group; $\mathrm{pH} 8.0$ group includes $\mathrm{pH} 8.0$ control, cellulase-added group, and DNase-added group. Supernatant and TB-EPS are the two representatives of the four fractions.

To distinguish the significance of difference among samples after different treatments, PCA was applied. Four factors (the concentration of each category of organic matters in the supernatant, slime, LB-EPS, and TB-EPS fractions) were analyzed and converted to two principal uncorrelated variables, thus formed a map in 
which samples distributed according to their influence by two dimensions, and four factors' contributions to principal variables were shown. The percentage of how much each principal component can explain the variance can also be calculated.

\section{Results and discussion \\ Reallocation of different organic matters Organic matters in the raw sludge}

Proteins, polysaccharides, and DNA comprised $70.5 \%$ of sludge organics on a VS basis and were the dominant components in EPS. Figure $1 \mathrm{a}-\mathrm{c}$ indicates the content of proteins, polysaccharides, and eDNA in each EPS fraction. To confirm the observed changes in organic substances that contained carbon or nitrogen, DOC (Fig. 1d) and DN (Fig. 1e) were assessed correspondingly. Raw sludge had $33.2 \%$ of proteins, $10 \%$ of polysaccharides, and $27.3 \%$ of the eDNA in EPS, and of these, 97 , 85 , and $95.3 \%$, respectively, were located in TB fraction. After treatments, the content in EPS was 11.5-40 \% for proteins and 24-43.5 \% for eDNA. For polysaccharides, the average total content of EPS was $2.7-15 \%$, but for the polygalacturonase treatment group, the EPS polysaccharide content was 55-73\%. And the location of each component significantly shifted from TB-EPS to LB-EPS, slime, and supernatant, in concern with the increase in treatment duration. Both DOC and DN followed the same trend. This may be owing to continuing enzymatic hydrolysis, sludge adsorption, and release of enzymes as they were still active.

\section{Redistribution of proteins}

The protein profiles after the various treatments exhibited three patterns: (1) in acid and neutral $\mathrm{pH}$ at $35{ }^{\circ} \mathrm{C}$, the concentration of EPS proteins generally decreased as incubation time increased; (2) in alkaline $\mathrm{pH}$ at $35^{\circ} \mathrm{C}$, the concentration of EPS proteins firstly decreased significantly but then recovered as treatment time increased; and (3) in all pH at $55{ }^{\circ} \mathrm{C}$, the total concentration of EPS proteins was unchanged, but redistribution of proteins occurred among fractions as the treatment duration increased. Contrary to expectations, the use of proteinase did not cause significant protein dissolution. Rather, compared to the $\mathrm{pH} 6.9$ control treatment without enzyme addition, proteinase caused some shift of proteins from the TB-EPS fraction to supernatant only under the $55^{\circ} \mathrm{C}$ treatment and caused no changes under the $35^{\circ} \mathrm{C}$ treatment. The effects of amylase addition were similar to that of proteinase addition; however, amylase shifted more proteins to slime. The use of cellulase did not produce significant changes compared to the $\mathrm{pH}$ 8.0 control treatment. After incubation of samples with added polygalacturonase for $1 \mathrm{~h}$ at $35{ }^{\circ} \mathrm{C}$, the proteins in supernatant were increased by ten times the content in raw sludge, but the supernatant content decreased as incubation duration increased, in agreement with the $\mathrm{pH}$ 4.0 control samples. The total amounts of EPS proteins in DNase-treated samples under both 35 and $55^{\circ} \mathrm{C}$ treatments reached and remained at about $38 \% \pm 1.5 \%$ of the proteins in sludge, and redistributions of these proteins occurred within EPS fractions. Noticeably, the decrease in the total amount of EPS proteins as incubation time increased in the alkaline treatment might have been caused by protein precipitation owing to denaturation and the assimilation of active microbes.

\section{Redistribution of polysaccharides}

The profile of EPS polysaccharides after the treatments followed four patterns: (1) in acid and neutral pH treatments at $35{ }^{\circ} \mathrm{C}$, the concentration increased slightly at first but then decreased as treatment duration increased; (2) in alkaline $\mathrm{pH}$ at $35{ }^{\circ} \mathrm{C}$, the concentration firstly decreased significantly but then recovered as treatment duration increased; (3) in acid and neutral $\mathrm{pH}$ at $55{ }^{\circ} \mathrm{C}$, the concentration increased as treatment duration increased; and (4) in alkaline $\mathrm{pH}$ at $55^{\circ} \mathrm{C}$, a significant quantity of polysaccharides shifted from the TB fraction to supernatant initially and continued this shift as treatment duration increased. The use of polygalacturonase had extraordinary effects on the dissolution and redistribution of polysaccharides. The total content of polysaccharides of EPS fractions reached 7 times that of raw sludge. Although the polysaccharides content in TB did not increase appreciably, the content in supernatant, slime, and LB increased by as much as $50 \% \pm 6 \%$ of the total polysaccharides content of raw sludge. In the cellulase treatment group at $55{ }^{\circ} \mathrm{C}$, the polysaccharides content shifted significantly from $\mathrm{TB}$ to supernatant, while there was no evident increase in the total content of polysaccharides in EPS. DNase addition caused the polysaccharides content to increase in the TB fraction but did not affect the content of polysaccharides in other EPS fractions. The distribution of polysaccharides among EPS fractions of samples in the amylase group (in both the 35 and $55^{\circ} \mathrm{C}$ treatments) showed little difference compared to the $\mathrm{pH} 6.9$ control group. The proteinase group in the $55^{\circ} \mathrm{C}$ treatment showed a minor increase in the polysaccharides content of supernatant.

\section{Redistribution of eDNA}

The profile of EPS eDNA after the treatments followed four patterns: (1) in acid and neutral $\mathrm{pH}$ at $35^{\circ} \mathrm{C}$, the concentration increased slightly at first and then decreased sharply and remained low until the end of treatment; (2) in alkaline $\mathrm{pH}$ at $35^{\circ} \mathrm{C}$, the concentration firstly decreased significantly and then slowly recovered 


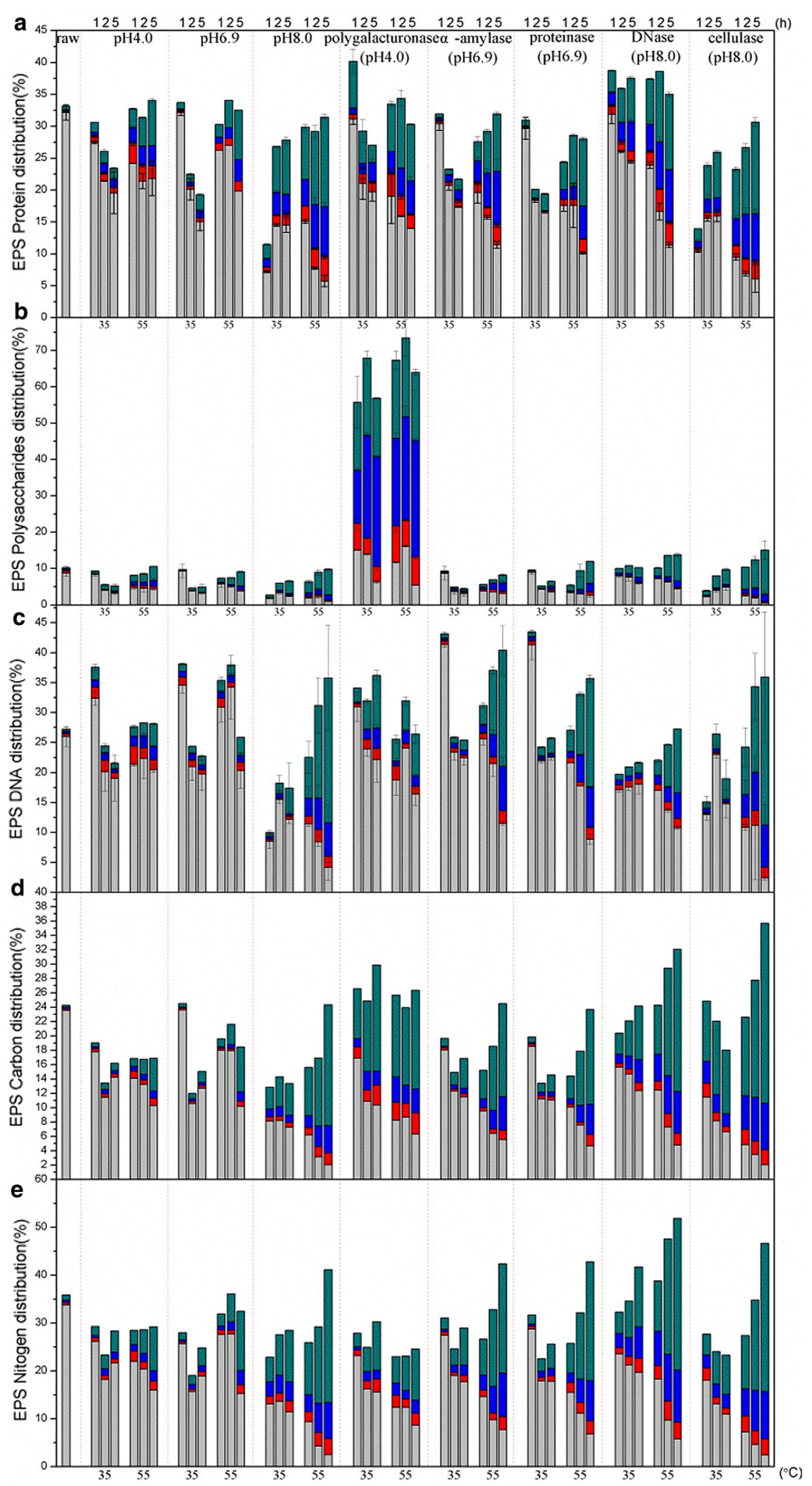

Fig. 1 Distribution of organic matters in EPS out of sludge. a EPS protein; b EPSPolysaccharides; $\mathbf{c}$ EPS DNA; d EPS Carbon; e EPS Nitrogen. Green square supernatant; blue square slime; red square loosely bound; gray square tightly bound. The rest proportion belongs to pellet and potential lossduring operation 
as treatment progressed, but remained low; (3) in acid $\mathrm{pH}$ at $55{ }^{\circ} \mathrm{C}$, the total concentration and distribution of eDNA remained constant; and (4) in neutral and alkaline $\mathrm{pH}$ at $55{ }^{\circ} \mathrm{C}$, a significant shift of eDNA occurred from the TB fraction to supernatant, slime, and LB fractions as treatment duration increased. Polygalacturonase (at $\mathrm{pH}$ 4.0) caused an approximately $7 \% \pm 2 \%$ shift of eDNA from the TB fraction to supernatant, slime, and LB fractions at both 35 and $55^{\circ} \mathrm{C}$, but the total concentration of eDNA at $35^{\circ} \mathrm{C}$ was higher than at $55^{\circ} \mathrm{C}$.

Amylase treatment (at $\mathrm{pH}$ 6.9) and proteinase treatment (at $\mathrm{pH}$ 6.9) affected eDNA distribution in similar ways. At $35^{\circ} \mathrm{C}$, both enzymes initially caused the eDNA concentration to increase significantly (compared to that in the raw sludge) to about $43 \%$ of the total amount of sludge, but the concentration decreased to its initial value as treatment duration increased, while the distribution among the EPS fractions remained relatively constant throughout treatment. At $55{ }^{\circ} \mathrm{C}$, amylase and proteinase caused significant increases in both the total amount of eDNA in EPS and the redistribution of eDNA from the TB to supernatant, slime, and LB fractions as treatment duration increased. The use of DNase (at $\mathrm{pH}$ 8.0) led to an initial decrease in the total amount of EPS, which slightly increased as treatment progressed, and although the distribution of eDNA in EPS did not change at $35^{\circ} \mathrm{C}$, eDNA gradually shifted to the supernatant and slime fractions at $55{ }^{\circ} \mathrm{C}$. Cellulase (at $\mathrm{pH}$ 8.0) did not shift eDNA among the EPS fractions, but the total amount of eDNA was affected at $35^{\circ} \mathrm{C}$. At $55^{\circ} \mathrm{C}$, cellulase treatment significantly increased both the total amount and redistribution of eDNA as treatment duration increased.

An additional file presented that the significance values from ANOVA analysis revealed the differences among groups with the same group, so the effect of each enzyme is highlighted out of $\mathrm{pH}$ adjustment (see Additional file 2).

\section{Redistribution of organics containing carbon}

Compared to that in the $\mathrm{pH} 4.0$ and $\mathrm{pH} 6.9$ controls, DOC and DN in the pH 8.0 control was redistributed to a larger extent at both 35 and $55^{\circ} \mathrm{C}$, and the $55^{\circ} \mathrm{C}$ treatment also resulted in an increase in the total concentrations. This effect of $\mathrm{pH}$ and temperature also applied to the enzyme addition samples. Amylase (at $\mathrm{pH}$ 6.9) and proteinase (at $\mathrm{pH}$ 6.9) treatments had very similar effects on DOC distribution; the two enzymes decreased the total amount of DOC in the $35{ }^{\circ} \mathrm{C}$ treatment and increased the DOC amount in the $55{ }^{\circ} \mathrm{C}$, with greater redistribution among the fractions. Similarly, the DNase (at pH 8.0) and cellulase (at pH 8.0) treatments had similar effects on DOC, but to a much larger extent. The polygalacturonase treatment (at $\mathrm{pH} 4.0$ ) caused changes in DOC that were different from those in the $\mathrm{pH} 4.0$ control group; the total amount of DOC was not the smallest, and the extent of redistribution was rather high. And the $55{ }^{\circ} \mathrm{C}$ treatment only showed minor difference from the $35^{\circ} \mathrm{C}$ treatment in terms of DOC redistribution.

\section{Redistribution of organics containing nitrogen}

The behavior of DN was very much like that of DOC, except that in the polygalacturonase treatment, DN changes corresponded strongly to those in the $\mathrm{pH} 4.0$ control samples. Higher $\mathrm{pH}$ and temperature treatments seemed to promote greater DOC and DN redistribution, and enzyme addition had comparatively less impact. As the additional file presented, the calculated quantities of carbon contained in proteins (Fig. 1a), polysaccharides (Fig. 1b), and eDNA (Fig. 1c), and of nitrogen contained in proteins and eDNA were generally consistent with DOC (Fig. 1d) and DN profiles (Fig. 1e) (see Additional file 3).

\section{PCA analysis on organic distribution profiles}

PCA results on each indicator for organics are shown in Fig. 2, which obviously observed the different effect of diverse treatments. From Fig. 2a-e, that the vector of "supernatant" is orthogonal to the vector "TB-EPS," which represents totally different distribution levels of organic matters. Temperature showed strong impact on EPS fractions distributing to supernatant and TB-EPS, with samples under $35^{\circ} \mathrm{C}$ treatments close to "TB-EPS," and samples under $55^{\circ} \mathrm{C}$ treatments closer to "supernatant." And samples showed patterns to gather according to different $\mathrm{pH}$ adjustments, too. Basically, the relative position of samples in the PCA results acted in coordination with content analysis above, especially on alkaline environment improving organic matters' release. Moreover, polygalacturonase's improvement on polysaccharides distribution to supernatant and cellulase promoting most kinds of organic matters release from TB-EPS are quite clear.

\section{Redistribution of dissolved fluorescent substances}

Fluorescent excitation-emission matrix analysis (EEM) was used to understand the extracellular distribution of recalcitrant organic matter (e.g., humic substances) which might contribute to the EPS biodegradability or dewaterability. The PARAFAC analysis of EEM data extracted two components that contributed $90.6 \%$ of spectrum data variation. Component I, which peaked at excitation (Ex) wavelengths of $220 / 280 \mathrm{~nm}$ and emission (Em) wavelengths of 306/356 nm (Fig. 3a), represented proteins and soluble microbial products. Component II, which peaked at Ex 220/240/290 nm and Em $364 \mathrm{~nm}$ (Fig. 3b), represented organic substances 

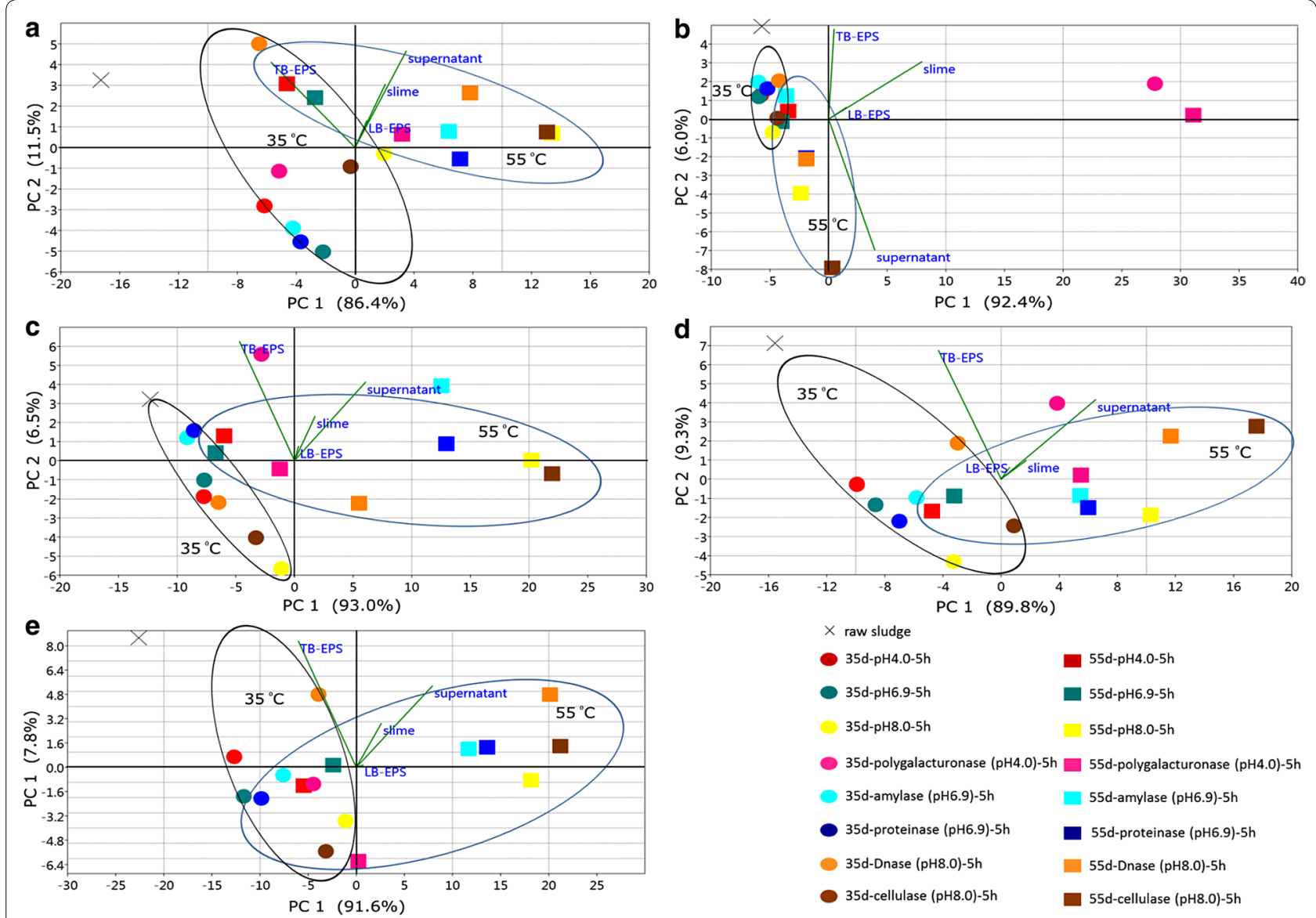

Fig. 2 PCA results of organic matters in different fractions. a EPS protein, b EPS polysaccharides, $\mathbf{c}$ EPS DNA, d EPS carbon, e EPS nitrogen

that had a higher degree of humification, according to the classification by Chen et al. [20] and Lü et al. [19]. The distribution of fluorescent substances is shown in Fig. 3c. It shows that the score of Component I was twice that of Component II in the amount among the groups, including raw sludge. In raw sludge, fluorescent substances were mostly distributed in the TB-EPS fraction and rarely in supernatant. The concentration ratio of Component I substances in supernatant to those in the TB-EPS fraction increased from 0.014 in raw sludge to 1.4 and 19.0 following the 35 and $55^{\circ} \mathrm{C}$ treatments, respectively. Similarly, the ratio of Component II substances in the supernatant to those in the TB-EPS fraction increased from 0.02 (raw sludge) to 1.48 and 19.8 following treatment at 35 and $55{ }^{\circ} \mathrm{C}$, respectively. Both the extent of redistribution and the total content of each component in supernatant were greater under the 55 treatment than in the $35{ }^{\circ} \mathrm{C}$ treatment. Like temperature, $\mathrm{pH}$ also played a role in the redistribution of fluorescent substances. The total content and extent of redistribution into supernatant were quite low in the $\mathrm{pH} 4.0$ control group, but both measures increased in the $\mathrm{pH} 6.9$ control group and increased further in the $\mathrm{pH} 8.0$ control group.

In the polygalacturonase treatment (at $\mathrm{pH} 4.0$ ), the two treatment temperatures $\left(35\right.$ and $55{ }^{\circ} \mathrm{C}$ ) had very similar effects on the total content and redistribution of fluorescent substances in the two EPS fractions. The amylase (at $\mathrm{pH}$ 6.9) and proteinase (at $\mathrm{pH}$ 6.9) enzymes had similar effects. Compared to raw sludge, both enzymes resulted in a lower total content of the substances in the TB-EPS, but a greater redistribution to supernatant under the $35{ }^{\circ} \mathrm{C}$ treatment, and almost the same total content and an even greater redistribution under the $55^{\circ} \mathrm{C}$ treatment. However, in the $35{ }^{\circ} \mathrm{C}$ treatment, amylase and proteinase caused the lowest redistribution of fluorescent substances from the TB-EPS fraction to supernatant among all enzymatic treatments. The DNase treatment (at $\mathrm{pH}$ 8.0 and $35{ }^{\circ} \mathrm{C}$ ) produced the greatest increases in the total content of fluorescent substances and in the redistribution of both components of fluorescent substances. At $35{ }^{\circ} \mathrm{C}$, the cellulase treatment (at $\mathrm{pH} 8.0$ ) produced changes like those in the $\mathrm{pH} 8.0$ control group; however, at $55{ }^{\circ} \mathrm{C}$ cellulase increased, the total content of 


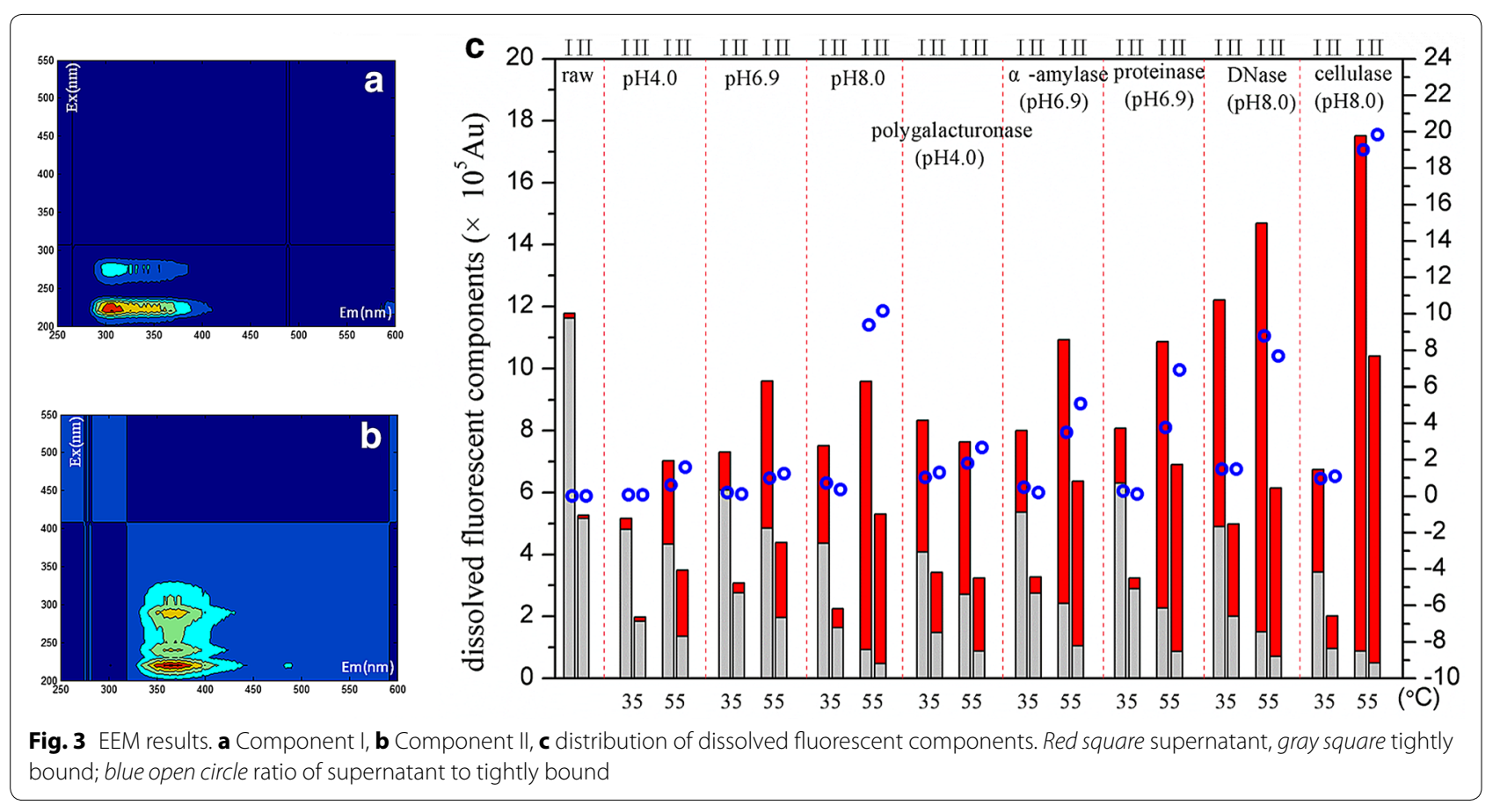

Component I and II substances by 48 and $100 \%$, respectively, compared to the content in raw sludge. In addition, among all enzyme treatments, cellulase caused the highest migration of fluorescent substances from the TB-EPS fraction to supernatant.

\section{Morphology changes of pellets}

Scanning electron microscopy was used to visualize the morphology of raw sludge and pellets after different treatments; the ESEM images are shown in Fig. 4. These images show differences between the microstructures of raw sludge and those of the pellets resulting from various treatments. Both raw sludge and the pellets demonstrated a rich spatial structure composed of porous "backbones," abundant EPS flocs, and thick superficial microbes, similar to what was reported by [21].

After enzymatic treatment and $\mathrm{pH}$ adjustment, a massive number of free particles were observed in samples. And the surficial microstructure abundance decreased more or less, especially in samples to which polygalacturonase, proteinase, and cellulase had been added. In the ESEM pictures of these three enzyme groups, "backbone," inorganic particle, and aggregate are seldom observed, and they appeared plainer and more homogenous. The pores inside individual particles became more dispersed and smaller. These structural changes could have reflected EPS disintegration. In fact, different treatments had distinctive morphological effects, which indicated different spatial distributions or roles of the hydrolyzed substrates in EPS formation.

Four types of changes in microstructure were observed. The first type of microstructure change was associated with the $\mathrm{pH} 6.9$ treatment, $\mathrm{pH} 4.0$ treatment, and polygalacturonase treatment (at $\mathrm{pH} 4.0$ ) in which the surface of the bulk raw sludge appeared smoother and less abundant of arches and filamentous structures than did the sludge pellet. The second type of microstructure change resulted from amylase treatment (at $\mathrm{pH}$ 6.9), $\mathrm{pH} 8.0$ treatment, and DNase treatment (at pH 8.0). The whole field of vision in ESEM images displayed rich superficial microstructures similar to the sludge pellet observation, but no apparent backbone could be observed. The third type of microstructure change was visible in the cellulase treatment (at $\mathrm{pH}$ 8.0). This type of change was characterized by a much plainer and simpler structure with only an accumulation of granules. The fourth type of microstructure change resulted from the proteinase treatment (at pH 6.9). The most distinctive feature of samples in this treatment was a vertical spatial structure, similar to that of a cave with inclined sleek walls tier upon tier.

From results observed in ESEM, some groups with different $\mathrm{pH}$ had similar morphology changes. It is clear that these differences did not caused by $\mathrm{pH}$ changes. Hence, the specific effect of each enzyme led to diverse types of EPS disintegration. 


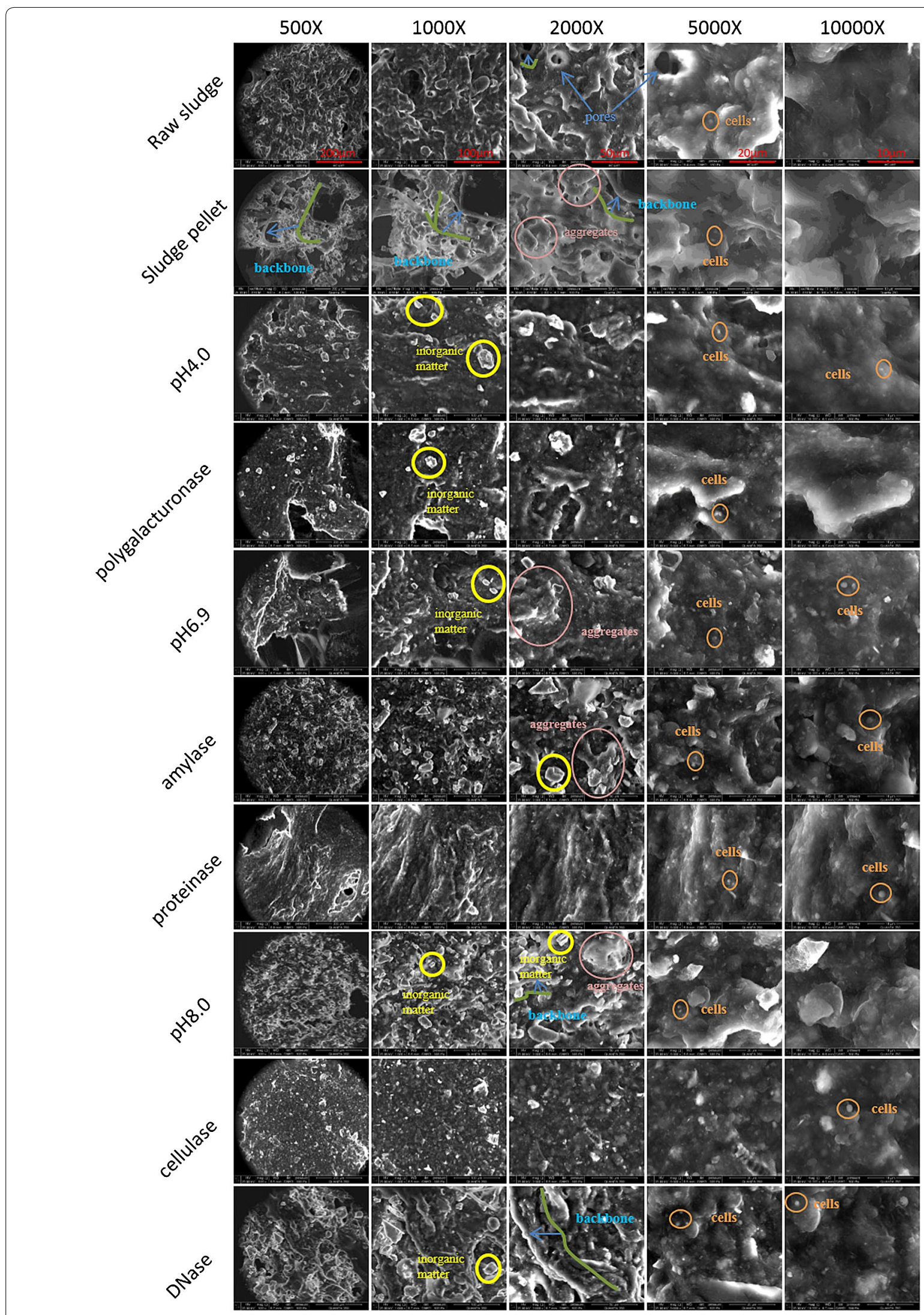

Fig. 4 ESEM results $(\times 500, \times 1000, \times 2000, \times 5000, \times 10,000)$ 


\section{Dewaterability of treated sludge}

The TS content of cake from raw sludge was $8.5 \% \mathrm{wt}$ and increased after treatment (Fig. 5). Within any treatment group, sludge that was treated at $55{ }^{\circ} \mathrm{C}$ showed higher dewaterability than when treated at $35^{\circ} \mathrm{C}$. Furthermore, cake TS decreased as $\mathrm{pH}$ increased. The TS of cake from $\mathrm{pH} 4.0$ control samples and from polygalacturonase (at $\mathrm{pH}$ 4.0) treatment samples reached $15 \%$ wt (the highest of all samples) quickly and remained high for all treatment durations, while the TS in cake from other treatments started at lower concentrations and increased as the duration of treatment increased. At the end of treatment, most treatments produced cakes that had a TS content over $12 \%$ wt in the $55{ }^{\circ} \mathrm{C}$ treatment and over $10 \%$ wt in the $35{ }^{\circ} \mathrm{C}$ treatment. In contrast, the TS content of cake from the DNase treatment decreased significantly to $6 \% \mathrm{wt}$, followed by increasing dewaterability; however, the dewaterability of DNase-treated sludge was not better than that of raw sludge.

\section{Role of temperature, $\mathrm{pH}$ and different hydrolases}

In this study, the quantity of organic substances released from the interior fraction (TB-EPS) of activated sludge to the exterior fraction (supernatant) was greater at higher $\mathrm{pH}$ and higher temperature, even without added enzymes. These results demonstrate that activated sludge flocs are very unstable in an alkaline environment and at high temperature (i.e., $55{ }^{\circ} \mathrm{C}$ ). Alkaline environment was widely applied to improve sludge's hydrolysis degree [14, 15], and it is reported that higher temperature could promote the abiotic dissolution of proteins [22]. And higher temperature could speed up the enzymatic hydrolysis so as to demonstrate larger impact on disintegrating sludge floc.

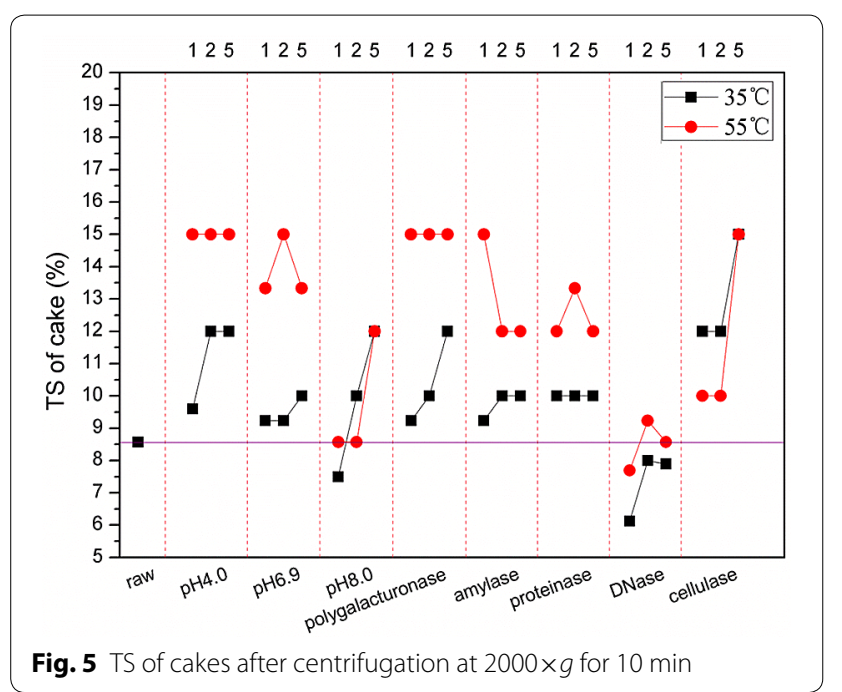

As shown in Figs. 1, 2 and 3, enzymes affected the release of organic matter from the inner fraction (TBEPS) to the most exterior fraction (supernatant) to different extents. Polygalacturonase was especially effective in mobilizing polysaccharides, with increases up to $700 \%$ in total EPS polysaccharides amount, compared with raw sludge. However, proteins and DNA were not released in large amounts in accordance with polysaccharides, which meant these three components were not from the same source (e.g., resulted from bacteria cell lysis). Hence, it is unlikely that massive polysaccharides came out of cells lysis. Furthermore, the DN content of sludge treated using polygalacturonase was released to a much less extent than by other enzyme treatments, and the $\mathrm{C} / \mathrm{N}$ ratio of polygalacturonase-treated samples decreased as incubation time increased. Combined with the ESEM results, which in this treatment were slightly different from those from the sludge pellet, the analytical results indicate that the polygalacturonic acid hydrolyzed by polygalacturonase has an important role in EPS floc formation (i.e., linkages of small flocs) but has no direct links with proteins or other organic matter that would be liberated when the linkages are broken. Hence, under polygalacturonase treatment, the polysaccharides content of sludge changed hugely, yet without a massive release of proteins or eDNA. Furthermore, compared with the ESEM observation of the $\mathrm{pH} 6.9$ control group, there was no obvious relationship with the surfaces of floc from the polygalacturonase-treated sludge, suggesting the substrate that is acted upon by polygalacturonase is too minor to introduce significant morphological change.

Cellulase treatment caused the release of all organic species at a relatively high level, as indicated by DOC (Fig. 1d), DN (Fig. 1e), and humic-like substances (Fig. 3). Since cellulase acts on cellulose, or the so-called beta-carbohydrate, which comprises $1.2-38.9 \% \mathrm{dw}$ [23] of active sludge, the plain microstructure may indicate that betacarbohydrate is the adhesive of the organic matter within the floc. When this adhesive was hydrolyzed by cellulase, the floc was dramatically broken down. As a result, the ESEM image of cellulose-treated sludge (Fig. 4) revealed a homogenous appearance that lacked structure.

\section{A proposed hypothesis on EPS biochemical distribution model}

Many conceptual models have been developed to elucidate the biological flocculation process and compositional distribution in the floc. The existing conceptual models can be classified into two types. In the first type, the whole floc is considered to be a gel-like matrix 
containing cell particles and organic colloids homogeneously bridged by various polymers and usually described using the Sierpinski carpet model [24-28]. In contrast, the second type of model considers the spatial distribution of biomass cells to be inhomogeneous, an interpretation mostly concluded from mathematical simulation of sludge floc growth, calculated parameters such as porosity, and morphological changes [29, 30]. Proteins, polysaccharides, and glycoproteins are considered to be the adhesive substances among microbial cells or between cells and attachable particles in the floc-forming process and are considered to be capable of influencing the subsequent treatable characteristics of activated sludge. These structural models normally consider the integrity of individual microbial cells or exopolymer particulates but rarely specifically describe the inner organic composition of cells and particulates; in addition, floc structures are usually described using particle size and porosity to distinguish among cells, fibers, and exopolymer.

However, asynchronous migration of carbon- and nitrogen-containing matter was observed in the present enzymatic study, as well as the unexpected hydrolysis efficiency of different enzymes. For example, polygalacturonase treatment changed the polysaccharides content of EPS significantly, yet without massive release of proteins or eDNA. The polysaccharide-releasing efficiency of polygalacturonase was far higher than that of the carbohydrases targeting amylum and cellulose, which were regarded as the major polysaccharides in EPS [5, 6]. In addition, the proteinase that targeted proteins, which comprised the majority of EPS organic material, was almost incapable of releasing protein; instead, DNase showed higher protein-releasing efficiency.

Therefore, the various objective polymers (e.g., proteins and polysaccharides) must have different spatial distributions within EPS. Much research on floc formation $[5,6,31]$ has accepted that cellulose might be the backbone for the whole floc structure. In the present study, when cellulose was hydrolyzed by cellulase, both proteins and polysaccharides appeared in very high amounts in all treatment conditions and were highly redistributed among EPS fractions. These results indicated that cellulose is the constructive substance for EPS, such that when this "backbone" was destroyed, the organic contents of the sludge were readily released.

However, the role of polygalacturonase cannot be discounted. Polygalacturonase is an enzyme that hydrolyses the alpha-1, 4 glycosidic bonds between galacturonic acid residues. Galacturonic acid originating from bacterial source, as reported in the references [32,33], is a component of bacterial polysaccharide and is important for cell structure. Frirdich and Whitfield [32] pointed out that Klebsiella pneumoniae 1 contains galacturonic acid residues that are proposed to serve a function in outer membrane stability. Ugalde et al [33] pointed out that a cell wall polymer containing galactose and galacturonic acid affects the bacterial strain's agglutinability with lectin and virus sensitivity. Hence, it is quite possible that polygalacturonic acid-like matter becomes a component of the adhesives that bind sludge floc. The elimination of polygalacturonic acid-like matter could result in the disintegration of the whole extracellular polymer substances matrix. As confirmed in the present study, when polygalacturonic acid-like matter was hydrolyzed, the content of polysaccharides in supernatant soared up extremely high, while the content of proteins did not increase (Fig. 1). Furthermore, polygalacturonase will not only target on the polygalacturonic acid of bacterial source abundant in sludge floc, but it can also act on the polygalacturon of plant source, i.e., pectin. Since municipal wastewater treatment plant accepts sewage containing plant fiber [34], the recalcitrantly biodegradable pectin in sewage will finally accumulate in sludge floc. As a result, the added polygalacturonase can also take some effect by acting on this component.

Hence, a plausible description of EPS (illustrated in Fig. 6) is that it consists of a large amount of small flocs in which major microbes and most proteins and other nitrogen-containing substances are firmly embedded. In addition, polygalacturonic acid-like matter might be a minor, but key, adhesive among small flocs, such that several small flocs together with fiber made of cellulose and other polysaccharides further construct the EPS. As a result, when polygalacturonic acid-like matter is hydrolyzed by polygalacturonase, cellulose and other polysaccharides are liberated, while proteins remain in the small flocs. If proteinase cannot access the protein aggregates and cells in small flocs easily, its efficiency in releasing proteins from sludge will be limited.

Nonetheless, the conceptual model needs experimental evidence to directly visualize the spatial distribution of exopolymers at nanometer scale. This requirement highlights the utility of high magnification microscopy combined with fluorescent probing or functional group probing techniques to revisit the structure of cell exopolymer, so as to better understand the relationship between sludge biochemical properties and sludge treatability. Currently, there are few published studies on the absolute content of polygalacturonic acid-like matter in sludge and EPS. Hence, the need is acute for research on this special minor organic species, as well as for an accurate determination method for the sludge matrix. 


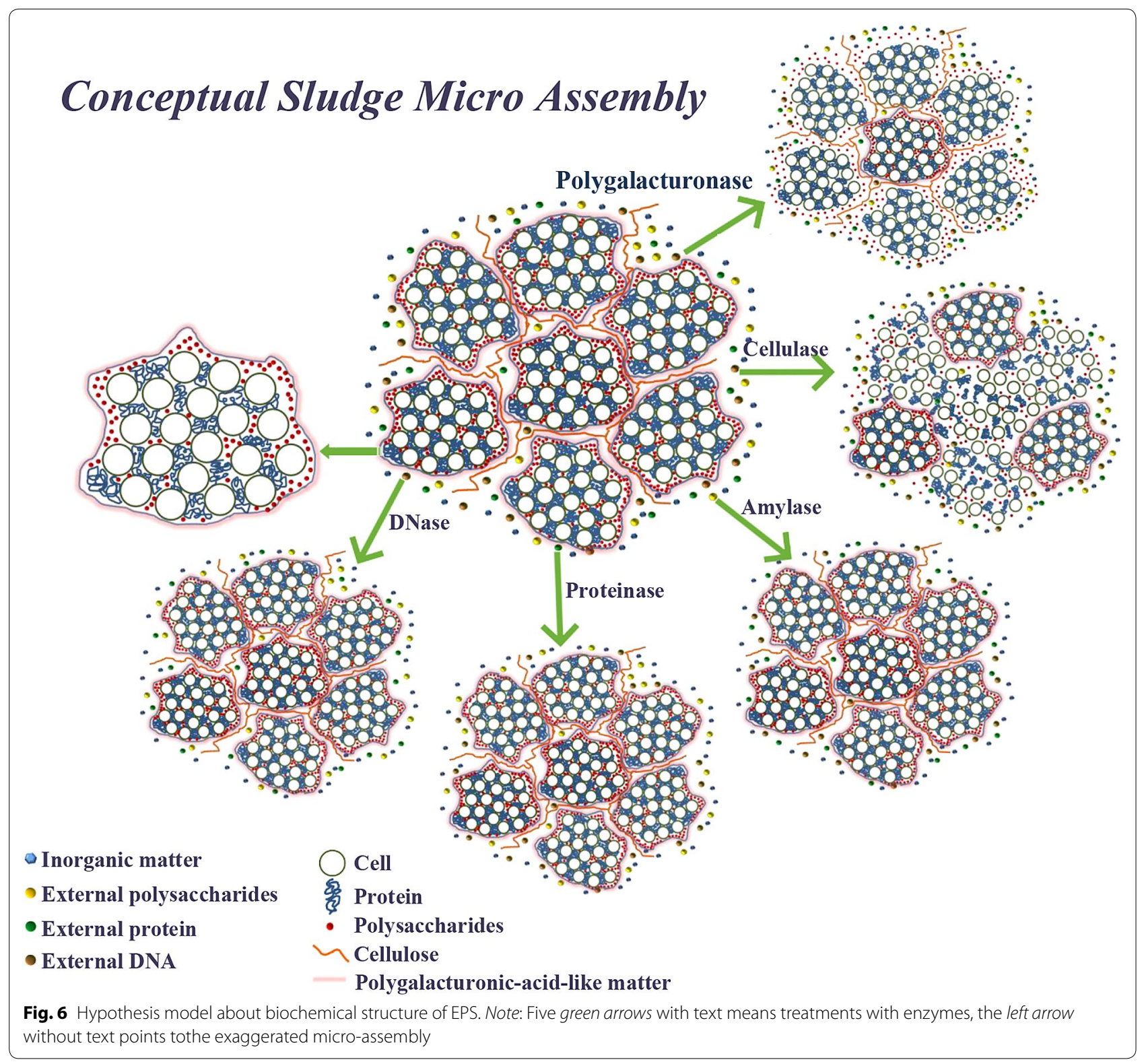

\section{Conclusions}

Although being minor, polygalacturonic acid-like matter and cellulose were observed to be key substances on the disintegration of sludge, according to the results of enzymatic treatment in this study. Hence, their roles in the structure and formation of EPS were proposed in a hypothesis model of sludge. As indicated in results, polygalacturonase and cellulase can be used to improve digestion and dewaterability of sludge. On the basis of single enzyme's effect, we suggest combinations of enzymes and multiple sludge sources be applied for further research. 


\section{Additional files}

Additional file 1. Procedure about the extraction of EPS fractions.

Additional file 2. ANOVA analysis of polysaccharides, protein and eDNA contents in supernatant and TB-EPS. In order to distinguish the effect of control group and experiment group at the same $\mathrm{pH}$, ANOVA analysis was applied on the contents of polysaccharides, protein and eDNA in supernatant and TB-EPS fraction. $\mathrm{pH} 4.0$ group includes $\mathrm{pH} 4.0$ control and pectinase-added group; $\mathrm{pH} 6.9$ group includes $\mathrm{pH} 6.9$ control, amylaseadded group and proteinase-added group; $\mathrm{pH} 8.0$ group includes $\mathrm{pH} 8.0$ control, cellulase-added group and DNase-added group. Supernatant and TB-EPS are the two representatives of the four fractions. The P-values of each group (pH 4.0, $\mathrm{pH} 6.9$ and $\mathrm{pH} 8.0)$ are presented.

Additional file 3. Calculation of carbon and nitrogen contained in organics. The obtained values on protein, polysaccharide and DNA in EPS were converted into the basis of carbon or nitrogen, according to their molecular formula. Accordingly, the equations for carbon calculation and nitrogen calculation were listed. The purpose of calculation was to compare with the directly measured values of DOC and DN. The calculation results are shown.

\section{Abbreviations}

EPS: extracellular polymeric substances; LB-EPS: loosely bound EPS; TB-EPS: tightly bound EPS; TS: total solids; VS: volatile solids; DOC: dissolved organic carbon; DN: dissolved nitrogen; eDNA: external DNA; EEM: excitation-emission matrix; PARAFAC: parallel factor analysis; ESEM: environmental scanning electron microscope; PCA: principal component analysis.

\section{Authors' contributions}

FL conceived the study; participated in three-dimensional fluorescent excitation-emission matrix analysis, parallel factor analyses, and data interpretation; and thoroughly reviewed the manuscript. JW carried out the treatments under different conditions, contents determination, EEM, ESEM, parallel factor analyses and all related analyses, data interpretation, and drafting and completion of the manuscript. LS participated in the design of the study and data interpretation, and reviewed the manuscript. PH participated in the design of the study and data interpretation, and reviewed the manuscript. All authors read and approved the final manuscript.

\section{Author details}

1 Present Address: State Key Laboratory of Pollution Control and Resources Reuse, Tongji University, 1239 Siping Road, Shanghai 200092, People's Republic of China. ${ }^{2}$ Institute of Waste Treatment and Reclamation, Tongji University, Shanghai 200092, People's Republic of China. ${ }^{3}$ Centre for the Technology Research and Training on Household Waste in Small Towns and Rural Area, Ministry of Housing and Urban-Rural Development (MOHURD) of China, Shanghai, People's Republic of China.

\section{Acknowledgements}

The authors would like to acknowledge the support from 973 Program (2012CB719801), NSFC (51378375, 51178327, 21177096), SHMEC Innovation Program (13ZZ030), Fundamental Research Funds for Central Universities (0400219272), the Collaborative Innovation Center for Regional Environmental Quality.

\section{Competing interests}

The authors declare that they have no competing interests.

Received: 26 November 2015 Accepted: 20 January 2016

Published online: 03 February 2016

\section{References}

1. Liu Y, Fang HHP. Influences of extracellular polymeric substances (EPS) on flocculation, settling, and dewatering of activated sludge. Crit Rev Environ Sci Technol. 2003;33(3):237-73.
2. Olkiewicz M, Fortuny A, Stüber F, Fabregat A, Font J, Bengoa C. Effects of pre-treatments on the lipid extraction and biodiesel production from municipal WWTP sludge. Fuel. 2015;141:250-7.

3. Braguglia CM, Gianico A, Gallipoli A, Mininni G. The impact of sludge pre-treatments on mesophilic and thermophilic anaerobic digestion efficiency: role of the organic load. Chem Eng J. 2015;270:362-71.

4. Pei J, Yao H, Wang H, Shan D, Jiang Y, Ma L, Yu X. Effect of ultrasonic and ozone pre-treatments on pharmaceutical waste activated sludge's solubilisation, reduction, anaerobic biodegradability and acute biological toxicity. Bioresour Technol. 2015;192:418-23.

5. Flemming $\mathrm{H}-\mathrm{C}$, Wingender J. The biofilm matrix. Nat Rev Micro. 2010;8(9):623-33.

6. McSwain BS, Irvine RL, Hausner M, Wilderer PA. Composition and distribution of extracellular polymeric substances in aerobic flocs and granular sludge. Appl Environ Microbiol. 2005;71(2):1051-7.

7. Chen Z, Zhang W, Wang D, Ma T, Bai R. Enhancement of activated sludge dewatering performance by combined composite enzymatic lysis and chemical re-flocculation with inorganic coagulants: kinetics of enzymatic reaction and re-flocculation morphology. Water Res. 2015;83:367-76.

8. Sesay ML, Özcengiz G, Dilek Sanin F. Enzymatic extraction of activated sludge extracellular polymers and implications on bioflocculation. Water Res. 2006;40(7):1359-66.

9. Yu S, Zhang G, Li J, Zhao Z, Kang X. Effect of endogenous hydrolytic enzymes pretreatment on the anaerobic digestion of sludge. Bioresour Technol. 2013;146:758-61.

10. Huang H, Ren H, Ding L, Geng J, Xu K, Zhang Y. Aging biofilm from a full-scale moving bed biofilm reactor: characterization and enzymatic treatment study. Bioresour Technol. 2014;154:122-30.

11. Teo CW, Wong PCY. Enzyme augmentation of an anaerobic membrane bioreactor treating sewage containing organic particulates. Water Res. 2014:48:335-44

12. Luo K, Yang Q, Li X-m, Yang G-j, Liu Y, Wang D-b, Zheng W, Zeng G. Hydrolysis kinetics in anaerobic digestion of waste activated sludge enhanced by a-amylase. Biochem Eng J. 2012;62:17-21.

13. Braun F, Hamelin J, Gévaudan G, Patureau D. Development and application of an enzymatic and cell flotation treatment for the recovery of viable microbial cells from environmental matrices such as anaerobic sludge. Appl Environ Microbiol. 2011;77(24):8487-93.

14. Yu G-H, He P-J, Shao L-M, He P-P. Toward understanding the mechanism of improving the production of volatile fatty acids from activated sludge at pH 10.0. Water Res. 2008;42(18):4637-44.

15. Chen Y, Jiang S, Yuan H, Zhou Q, Gu G. Hydrolysis and acidification of waste activated sludge at different pHs. Water Res. 2007;41(3):683-9.

16. Yu G-H, He P-J, Shao L-M, Zhu Y-S. Extracellular proteins, polysaccharides and enzymes impact on sludge aerobic digestion after ultrasonic pretreatment. Water Res. 2008;42(8-9):1925-34.

17. Gaudy AF. Colorimetric determination of protein and carbohydrate. Ind Water Wastes. 1962;7:17-22.

18. Markwell MAK, Haas SM, Bieber LL, Tolbert NE. A modification of the Lowry procedure to simplify protein determination in membrane and lipoprotein samples. Anal Biochem. 1978;87(1):206-10.

19. Lu F, Chang C-H, Lee D-J, He P-J, Shao L-M, Su A. Dissolved organic matter with multi-peak fluorophores in landfill leachate. Chemosphere. 2009;74(4):575-82.

20. Chen W, Westerhoff P, Leenheer JA, Booksh K. Fluorescence excitationemission matrix regional integration to quantify spectra for dissolved organic matter. Environ Sci Technol. 2003;37(24):5701-10.

21. Holbrook RD, Wagner MS, Mahoney CM, Wight SA. Investigating activated sludge flocs using microanalytical techniques: demonstration of environmental scanning electron microscopy and time-of-flight secondary ion mass spectrometry for wastewater applications. Water Environ Res. 2006;78(4):381-91.

22. Lü F, Li T, Wang T, Shao L, He P. Improvement of sludge digestate biodegradability by thermophilic bioaugmentation. Appl Microbiol Biotechnol. 2013;98(2):969-77.

23. Honda S, Apos ICHI, Miyata N, Iwahori K. A survey of cellulose profiles in actual wastewater treatment plants. Jpn J Water Treat Biol. 2000;36:9-14

24. Jorand F, Zartarian F, Thomas F, Block JC, Bottero JY, Villemin G, Urbain V, Manem J. Chemical and structural (2D) linkage between bacteria within activated sludge flocs. Water Res. 1995;29(7):1639-47. 
25. Nielsen $\mathrm{PH}$, Keiding K. Disintegration of activated sludge flocs in presence of sulfide. Water Res. 1998;32(2):313-20.

26. Gorczyca B, Ganczarczyk J. Structure and porosity of alum coagulation flocs. Water Qual Res J Can. 1999:34(4):653-66.

27. Liu L, Sheng G-P, Liu Z-F, Li W-W, Zeng RJ, Lee D-J, Liu J-X, Yu H-Q. Characterization of multiporous structure and oxygen transfer inside aerobic granules with the percolation model. Environ Sci Technol. 2010;44(22):8535-40.

28. Chen M-Y, Lee D-J, Yang Z, Peng XF, Lai JY. Fluorecent staining for study of extracellular polymeric substances in membrane biofouling layers. Environ Sci Technol. 2006;40(21):6642-6.

29. Takács I, Fleit E. Modelling of the micromorphology of the activated sludge floc: low do, low F/M bulking. Water Sci Technol. 1995;31(2):235-43.
30. Scuras S, Daigger GT, Leslie Grady CP Jr. Modeling the activated sludge floc microenvironment. Water Sci Technol. 1998;37(4-5):243-50.

31. Dumitriu S. Polysaccharides: structural diversity and functional versatility. Boca Raton, FL: CRC Press; 2004.

32. Frirdich $E$, Whitfield C. Characterization of GlaKP, a UDP-galacturonic acid C4-epimerase from Klebsiella pneumoniae with extended substrate specificity. J Bacteriol. 2005;187(12):4104-15.

33. Ugalde RA, Coira JA, Brill WJ. Biosynthesis of a galactose-and galacturonic acid-containing polysaccharide in Rhizobium meliloti. J Bacteriol. 1986;168(1):270-5.

34. Ghasimi DSM, de Kreuk M, Maeng SK, Zandvoort MH, van Lier JB. Highrate thermophilic bio-methanation of the fine sieved fraction from Dutch municipal raw sewage: cost-effective potentials for on-site energy recovery. Appl Energy. 2016;165:569-82.

\section{Submit your next manuscript to BioMed Central} and we will help you at every step:

- We accept pre-submission inquiries

- Our selector tool helps you to find the most relevant journal

- We provide round the clock customer support

- Convenient online submission

- Thorough peer review

- Inclusion in PubMed and all major indexing services

- Maximum visibility for your research

Submit your manuscript at www.biomedcentral.com/submit
Biomed Central 